УДК 821.161 .2

() С. Б. Фіялка, канд. наук із соц. ком., доцент, КПІ ім. Ігоря Сікорського, Київ, Україна

\title{
ПІЗНАВАЛЬНИЙ ТА ВИХОВНИЙ ПОТЕНЦІАЛ БЕЛЕТРИЗОВАНИХ БІОГРАФІЙ ДЛЯ ДІТЕЙ
}

Досліджено біографічні видання про видатних особистостей, призначені для дитячої читацької аудиторії. 3'ясовано, що дедалі частіше автори відходять від традиційних енциклопедичних форм подання біографій за усталеними схемами, схиляючись у бік художнього викладу. Схарактеризовано принципи добору фактів та виявлено розмаїття прийомів популяризації відомих постатей в україномовних белетризованих біографіях для дітей; розкрито виховний потенціал таких видань. Жанр белетризованої біографії дає змогу персоналізувати історію, розвивати мотивацію, пробуджувати потребу в пізнанні навколишнього світу, що постійно супроводжує дорослішання та соціалізацію юного читача. Серед канонів побудови белетризованої біографії можна виокремити правдивість зображення головного героя, використання мовностилістичних засобів, глибоке занурення

в психологію особистості, добір цікавих і шокуючих фактів, гармонійне поєднання правди і вимислу.

Ключові слова: белетризована біографія; художньо-біографічний твір; біографічна проза; популяризація; дитяча аудиторія.

\section{Постановка проблеми}

Біографічна проза відома ще з античних часів, однак і нині вона не втратила своєї актуальності. Протягом останнього десятиліття в Україні відчутно зріс суспільний інтерес до біографічних видань про видатних особистостей, зокрема книг, призначених для дитячої читацької аудиторії. Це зумовлено, насамперед, значним пізнавальним та розвивально-виховним потенціалом такої літератури. Прикметно, що дедалі час- тіше автори відходять від традиційних енциклопедичних форм подання біографій за усталеними схемами, схиляючись у бік художнього викладу. Автори експериментують із формою біографій та приділяють значну увагу психології видатної особистості, мотивації її вчинків. Відтак актуалізується потреба дослідити принципи добору фактів, виявити розмаїття прийомів популяризації відомих постатей у біографіях для дитячої читацької аудиторії.

(C) $2018 \mathrm{p}$. 


\section{Аналіз попередніх досліджень}

Т. Черкашина уточнила термінологічний апарат, розширила теоретичну класифікацію біографічної прози (зокрема, уперше ввела в науковий обіг поняття «біографічна лакуна», «біографічна мозаїка», «змістовно-смислові художні біографії», «формалізовані життєписи») [1]. Теоретикометодичні та історичні аспекти біографіки для дітей вивчали Н. Марченко [2, 3] та М. Семенченко [4]. О. Галич ґрунтовно дослідила документально-біографічні твори, проаналізувала відмінність історичної та біографічної прози й визначила найбільш суттєві ознаки біографічних творів: конкретність одиничної долі (узагальнення життєвого досвіду в одній реальній людській постаті, через яку проходить уся різноманітність явищ історії); герой перебуває в центрі подій (ніхто і ніщо не може витісняти його за межі сюжету); ступінь і якість художнього вимислу та домислу обмежені, бо автор прив'язаний до біографії персонажа [5]. У біографічній літературі наявні такі провідні ознаки документальної літератури, як «естетичний та психологічний аспекти, помножені на авторську емоційність і самоаналіз» [6].

Жанрово-стильовим особливостям, а також типології сучасної біографічної прози для дітей присвячено статтю Л. Овдійчук [7]. Зокрема, авторка виділила такі різновиди біографічної літератури для дітей: художня біографія про видатних осіб; історикобіографічні твори (повісті та оповідання); автобіографічні твори письменників.
Очевидно, що «поєднання фактичної точності та переконливості сюжету - найважче під час написання біографії» [8]. За читацьким інтересом до біографії завжди стоїть потреба побачити красиву й багату людську особистість, цілісність центрального образу [9].

Попри значний інтерес науковців до літератури, що презентує біографічне знання, досі поза увагою дослідників залишається розмаїття засобів, за допомогою яких автори дитячої літератури досягають контакту із читачем, збуджують його цікавість, інтерес до життєписів відомих осіб, відходячи від монотонності та шаблонності енциклопедичного біографічного викладу.

\section{Мета роботи}

Схарактеризувати принципи добору фактів та виявити розмаїття прийомів популяризації відомих постатей у белетризованих біографіях для дітей; розкрити виховний потенціал таких видань.

\section{Результати проведених досліджень}

У Літературознавчому словнику-довіднику біографія трактується як розповідь про життєвий шлях людини, найчастіше у зв'язку з важливими суспільними подіями того часу, коли вона жила. Тим часом під белетристикою розуміється проза (романи, повісті, новели, есе), для якої характерні трансформація фабули в гострий сюжет, інтрига, несподівані перипетії, що викликають жвавий читацький інтерес [10]. У вузькому буденному розумінні белетристикою вважають легку літературу для читання на дозвіллі. 
Під белетризованою біографією для дітей ми розумітимемо оповіді, викладені в розважальній, доступній формі, які популяризують відомих постатей із царини науки, мистецтва, спорту, політики тощо серед дитячої читацької аудиторії. Така література спрямована одночасно як на духовне, емоційне, естетичне виховання дитини, так і на формування її інформаційної культури та становлення природної потреби в пізнанні навколишнього світу. У результаті белетризована біографія синтезує в собі риси як белетристики, так і біографічної літератури, та підпорядковується, відповідно, законам внутрішнього розвитку кожного із жанрів. Автор белетризованої біографії «не ставить перед собою завдання точно описати події та людей, тому вона не може слугувати документальним свідченням» [11]. Однак практика користування такими виданнями «виробляє в читача звичку отримувати знання не лише зі шкільних підручників, а й з інших джерел, тобто орієнтує дитину на позашкільне навчання, на самоосвіту та самовдосконалення» [12].

Серед такої літератури, наявної на ринку України, однією з перших стала книжкова серія видавництва «Грані-Т», заснована 2006 р. До серії ввійшло понад 30 книжок сучасних українських літераторів: Андрія Кокотюхи, Ірен Роздобудько, Івана Андрусяка, Анни Багряної, Лариси Денисенко, Леоніда Кононовича, Любко Дереша, Богдана Жолдака, Яни Дубинянської, Богдана Логвиненка.

«Видавництво Старого Лева» видало біографії фундаторів української культури Івана Франка,
Андрея Шептицького, Тараса Шевченка та Богдана-Ігоря Антонича. Видавництво «К.І.C.»серію про дослідників і науковців «Спалах думки» авторства Луки Новеллі, де оповіді ведуться від першої особи. Цікавою $є$ також серія біографій від агентства «IPIO» «Видатні особистості. Біографічні нариси для дітей», до якої належать книжки про Маргарет Тетчер, Одрі Хепберн, Ніколу Теслу, Блеза Паскаля, Чарлі Чапліна, Вільяма Шекспіра, Марію Кюрі, Альберта Ейнштейна, Леонардо да Вінчі, Коко Шанель, Стіва Джобса, Ілона Маска, Леоніда Каденюка, Ігоря Сікорського. Особливістю книг серії $€$ те, що видатні персоналії постають перед юними читачами як герої творів пригодницького жанру.

3-поміж белетризованих біографій тільки про жінок варто відзначити серію «Маленьким про великих» видавництва «КМ-Букс», створену у вигляді книжок-картинок, де основне смислове навантаження несуть ілюстрації. Ще однією серією белетризованих біографії про видатних жінок стала «Міранда» видавництва «Nebo Booklab Publishing».

Проаналізувавши названі видання, можна виокремити загальний каркас фактичної біографічної інформації, наявної в цій літературі:

1. Дата й місце народження та смерті.

2. Інформація про родину.

3. Найвизначніші досягнення.

4. Основні події в житті.

5. Вплив на суспільство, історичне значення постаті.

На цей каркас нанизуються факти, які здатні вразити читача, 
утримати його увагу, «оживити» зображувану постать та історичний контекст, у якому ця постать жила і творила. Відтак автори додатково звертають увагу на такі аспекти біографії:

Які події з дитинства вплинули на формування особистості?

Які риси характеру посприяли успіху цієї особистості?

Які почуття вона переживала впродовж життя?

Саме така додаткова інформація популяризує виклад, зацікавлює читача. Розглянемо окремі прийоми, якими послуговуються автори названих вище видань, а також студенти спеціалізації «Видавнича справа та редагування» НТУУ «КПІ ім. Ігоря Сікорського», які створювали белетризовані біографії на практичних заняттях із дисципліни «Редагування дитячих видань».

Зацікавити читача може нетривіальний початок, в основі якого цікавий факт, надзвичайна подія, фантастичний образ чи заохочення до дії, наприклад: «Погляньте на карту Великої Британії. Якщо трошки пофантазувати, можна побачити обриси дракона або товстої ящірки, яка стоїть на задніх лапах. У нижньому лівому кутку хвіст, у верхньому правому роззявлена паща (Вздульська В. Вільям Шекспір. Київ: IPIO, 2018. С. 10). Інший приклад слова, якими могла б починатися біографія Джона Леннона: «У давнину вважалося, що від того, яка погода панує в день твого народження, залежить, якої ти в майбутньому будеш вдачі. Якщо це справді так, то я, мабуть, щасливчик. Адже я, Джон Вінстон Леннон, народився просто під час нальоту німецької авіації на
Ліверпуль зранку 9 жовтня 1940 року» (авторка біографії про Джона Леннона - студентка Анна Манченко).

Автори надихають дітей, наводячи буденні фрагменти із життя великих людей, згадки про спільні інтереси героя та читача. Наприклад, коли проводяться паралелі між дитинством героя історії та юного читача: «Я вправно будую складні споруди з різнокольорових дерев'яних кубиків, попередників теперішніх конструкторів «Лего» (Новеллі Лука. Айнштайн та машина часу. Київ: К.І.С., 2016. С. 16).

На нашу думку, зацікавити читача здатні також шокуючі факти. Наприклад: «До речі, ви не думали чому мене звуть саме так, Оззі? Що, не знаєте? Я теж не знаю. Ні-ні, це не від книжки про країну Оз. Що ви, що ви? Прізвисько це дали ще в школі, 3 якої мене, до речі, років у 15 вигнали. Не те щоб я був закінченим розбишакою, просто в нас не було грошей на мою освіту. I я пішов... у різники, бугага! До того ще правда намагався працювати слюсарем, і ще згодом малярем, і навіть гробарем» (авторка біографії про Оззі Осборна студентка Анна Шевчук).

Увагу читача можуть привернути також оповіді про смішні події з життя описаної в біографії особи. Наприклад: «Я конструюю кукурудзяні гармати. Але мій експеримент завершується, щойно я розбиваю шибку в нашому домі» (Новеллі Лука. Тесла та машина на космічній енергії. Київ: K.І.C., 2017. C. 19). Так само образи з книг Видавництва Старого Лева (про Івана Франка, Тараса Шевченка та ін.) стають набагато 
ближчими читачам, адже зображені через побут, кумедну колажну форму. Це більше не далекі іконічні образи, а близькі до читачів за вподобаннями й життевими буднями люди.

Утримувати увагу читача може й зображення рис характеру героя, який не боїться порушувати правила, бунтувати й кидати виклик: «Я ненавиджу вдягати форму та ходити на парад - робити те, що від нас, молодого покоління Німеччини, вимагають щоп'ятниці, щосуботи та щонеділі. Ненавиджу завчати щось напам'ять, і тому викладач грецької мови каже, що я нічого не досягну в своєму житті» (Новеллі Лука. Айнштайн та машина часу. Київ: К.І.С., 2016. С. 21); «Я хотів би одружитися з Мілевою, але в нас не вистачить грошей навіть на купівлю двох велосипедів для прогулянок селом. Крім того, мої батьки проти нашого одруження, та я все одно одружуся з нею. Я так вирішив» (Новеллі Лука. Айнштайн та машина часу. Київ: К.І.С., 2016. С. 40).

Привернути увагу читача можуть також згадки про дивакуватість головного героя, наголос на його особливостях, наприклад: «Я не зношу волосся інших людей. Я б до нього не доторкнувся навіть під дулом пістолета. Я міг би захворіти, дивлячись на пушок персика... Я рахую все, що бачу чи роблю, все, що навколо мене... Усе довкола, навіть шматочки, які кладу до рота, має ділитися на три...» (Новеллі Лука. Тесла та машина на космічній енергії. Київ: К.І.С., 2017. С. 23-24); «Ще я боюся мікробів. Я мию руки дев'ять разів на день і тричі протираю ручки дверей, перш ніж до них доторкнутися. Заради гігієни я не вітаюся ні з ким за руку, а якщо і роблю це, то одягаю рукавички: при собі в мене завжди щонайменше три пари (Новеллі Лука. Тесла та машина на космічній енергії. Київ: К.І.С., 2017. С. 69). Не зайвою буде й атмосфера таємничості, яка може надати образу додаткової харизматичності та пробудити допитливість юного читача, його інтерес до художника, ученого чи мислителя.

На нашу думку, вдалим прийомом $€$ введення фактів, що засвідчують невдачі й розчарування головного героя біографії. Це наближає його до звичайної людини. Однак поразки не руйнують героїв, а лише загартовують, роблять сильнішими. Наприклад: «У 1895 році, після моєї спроби скласти вступний іспит до Цюріхського політехнікуму, мене, Альберта Айнштайна, не зарахували» (Новеллі Лука. Айнштайн та машина часу. Київ: К.І.С., 2016. С. 11); «Я знаходжу акціонерів, які здаються мені надійними... Як же я помиляюся. Коли підприємство запущене, я залишаюся без грошей і з купою боргів. Мене звільняють з компанії, яку я сам і заснував. Я не маю ані копійки і змушений шукати роботу, щоб якось вижити. Тому я стаю землекопом і різноробом...» (Новеллі Лука. Тесла та машина на космічній енергії. Київ: K.I.C., 2017. C. 36-37).

Не чужі для великих і звичайні людські слабкості та пороки. Наприклад: «Оскільки мені подобається смачно поїсти, я трохи розтовстів» (Новеллі Лука. Айнштайн та машина часу. Київ: К.І.С., 2016. С. 67); «У дитинстві я не був хлопчиком зі зразковою поведінкою, 
я досить часто сварився, інколи вживаючи погані слова, розповідав купу неймовірних вигадок, щоб підлеститись до дорослих» (Новеллі Лука. Дарвін та невигадана історія про динозаврів. Київ: К.І.С., 2016. С. 15); «Окрім дивацтв, в юнацтві я мав один порок: азартні ігри. Це дуже турбувало моїх батьків, адже за гральним столом я програвав завжди і багато. Мене обдирали як барана. Потім я переборов цю нездорову звичку. 3 числами можна грати, але обіграти їх неможливо... Безкінченно більше задоволення мені дають мої винаходи і робота» (Новеллі Лука. Тесла та машина на космічній енергії. Київ: К.І.С., 2017. C. 25).

Цікавими в белетризованих біографіях $€$ кінцівки. Зокрема, досвід того, як зобразити смерть у виданнях для дитячої аудиторії. На нашу думку, вельми доречні кінцівки, наявні в Луки Новеллі, наприклад: «11 квітня 1955 року я пишу другові Бертрану Расселу, підписуючи заклик до всіх країн світу відмовитися від атомної зброї. Це мій останній лист. Мій останній жест» (Новеллі Лука. Айнштайн та машина часу. Київ: К.І.С., 2016. С. 81); «Одним словом, мені вже часіти. Моядуша спокійна» (Новеллі Лука. Дарвін та невигадана історія про динозаврів. Київ: К.І.С., 2016. С. 81); «Зараз надворі йде дрібний сніг з дощем. Треба сказати, щоб покоївка придивилася за моїми голубами» (Новеллі Лука. Тесла та машина на космічній енергії. Київ: К.І.С., 2017. С. 81). Подібні кінцівки оминають тему смерті, але водночас автор залишається чесним із читачем.

Ще один приклад відносно оптимістичної кінцівки - 3 неопуб- лікованої біографії Джона Леннона (авторка - студентка Анна Манченко): «Збулося! Жити б тепер та радіти, та от вельми поширений стереотип: думати, що коли ти - знаменитість, то й жити маєш довго та щасливо. Аж ніяк! Життя навіть тоді любить підкладати тобі свиню. Надто коли його в тебе відбирають: несподівано, та ще й людина, якій ти кілька годин тому давав автограф. От халепа!».

Окремої уваги в організації викладу й контакту із читачем заслуговують тематичні словники та питання й завдання. Наприклад, у всіх книжках Луки Новеллі подано тематичний словничок (зоряний, електро-, дарвінівський, відносний), де в доступній формі пояснені терміни й винаходи, до яких мав причетність кожен із дослідників, а також згадано їхніх колег. У серії від видавництва «IPIO» «Видатні особистості. Біографічні нариси для дітей» наприкінці кожної глави міститься добірка питань, які допомагають дитині запам'ятати найголовніше та зробити власні висновки.

Якщо говорити про виховний аспект белетризованих біографій, то в окремих виданнях, попри пригодницько-розважальну нарацію, наявний прихований дидактизм, який потенційно може впливати на формування морально-етичних позицій та ціннісних орієнтацій читача. Наприклад: «Багатство й успіх ніколи не були моєю метою. А ось почуття, краса та правда мені справді осявали життя, сповнюючи мене силою й радістю» (Новеллі Лука. Айнштайн та машина часу. Київ: К.І.С., 2016. С. 11); «Ніколи не варто руйнувати мости, не будучи певним, що дістанешся протилежного берега» 
(Новеллі Лука. Айнштайн та машина часу. Київ: К.І.С., 2016. С. 55).

Реалізується виховна функція белетризованих біографій і тоді, коли герої постають як зразки для наслідування: «Він був дуже допитливим. Його цікавило геть усе, до найменшої дрібниці. Він про все на світі запитував, а якщо не отримував відповіді на своє запитання, то намагався знайти іï самотужки. Його цікавило геть усе. 3 чого складається той чи інший прилад? Чому деталі з'єднуються саме в такому порядку? І що буде, якщо поміняти дроти місцями? Чи подаватиме прилад сигнал? Якщо не подаватиме, то чому? А якщо подаватиме, то яким буде цей сигнал? Такий само потужний? Чи, можливо, менший, але змінить частоту?» (Сердюк М. Стів Джобс. Київ: IPIO, 2018. С. 11). У наведеному прикладі як позитивна риса зображується допитливість. Крім того, раз за разом герої белетризованих біографій постають як любителі читання, наприклад: «Ілон ковтав книжки. Двісті сторінок він спокійно «з'їдав» за кілька годин. Без книжки в руках Ілона не бачили майже ніколи. Одну за одною він поглинав фантастичні пригоди, комікси, наукову та спеціальну літературу. Одного дня виявилося, що в бібліотеці не лишилося жодної книжки, якої б не прочитав Ілон» (Сердюк М. Ілон Маск. Київ: IPIO, 2018. С. 10).

\section{Висновки}

Підсумовуючи результати дослідження, зауважимо, що, готуючи белетризовану біографію, автор мусить зануритися в літописи, мемуари, щоденники, листи, спогади сучасників відповідної особи, а також довідкову й художню літературу, аби накреслити загальний сюжет оповіді, а потім наповнити цей сюжет найцікавішими фактами та яскравими побутовими деталями, при цьому щоразу зважуючи їх важливість та здатність зацікавити читача. При цьому автор має враховувати, що особистість формується під впливом епохи, прийнятих у суспільстві на той час моральноетичних норм та моделей поведінки.

Жанр белетризованої біографії дає змогу персоналізувати історію, розвивати мотивацію, пробуджувати потребу в пізнанні навколишнього світу, що постійно супроводжує дорослішання та соціалізацію юного читача. Такі твори виконують не лише пізнавальну та виховну функцію, а й розважальну. Хоча це ще не суто художня література, але вже й не документалістика. Те, що читач ще занадто юний, лише ускладнює завдання автора біографії: попри те, що він має досконало знати життєпис зображуваної особистості, він також має добре володіти мовою популяризації, тобто повинен уміти розповісти про складні поняття дохідливо й захопливо.

Серед канонів побудови белетризованої біографії можна виокремити правдивість зображення головного героя, використання мовностилістичних засобів, глибоке занурення в психологію особистості, добір цікавих і шокуючих фактів, гармонійне поєднання правди і вимислу. Життя людини зіткане з відчуттів, історій та емоцій, а не лише з дат у хроно- 
логічній послідовності. Тож саме в белетризованих біографіях за шаблонними енциклопедичними образами з'являється яскрава індивідуальність видатних постатей. Добре написана белетризо- вана біографія наближає зображуваний в ній образ до читача, досягаючи ефекту присутності, створення ілюзії участі читача у звершеннях, мандрах та експериментах головного героя.

\section{Список використаної літератури}

1. Черкашина Т. Наративні особливості художньо-біографічної прози: автор і читач: автореф. дис. ... канд. філол. наук: 10.01.06. Тернопіль, 2007. $22 \mathrm{c}$.

2. Марченко Н. Соціокультурні стереотипи в новітній українській біографіці для дітей / Н. Марченко // Бібліот. вісн. 2011. № 1. С. 149-174.

3. Марченко Н. Біографічна інформація у виданнях для дітей у контексті сучасних завдань біографістики / Н. Марченко // Укр. біографістика: зб. наук. пр. 2010. Вип. 7. С. 105-144.

4. Семенченко М. I генії були малими [Електронний ресурс] // ЛітАкцент. URL: http://litakcent.com/ 2010/09/10/i-heniji-bulymalymy.html (дата звернення: 22.11.2018).

5. Галич О. Fiction i non Fiction в літературі: проблеми теорії та історії: монографія / О. Галич. Луганськ: СПД Рєзніков В. С., 2013. 368 с.

6. Колінько О. Нон-фікшн як особливий феномен сучасної белетристики / О. Колінько // Наук. вісн. Міжнар. гуманіт. ун-ту. 2016. № 24. С. 76.

7. Овдійчук Л. Жанрово-стильові особливості сучасної біографічної прози для дітей / Л. Овдійчук // Питання літературознавства. 2014. № 90. С. 156-169.

8. Schroeder A. Writing a life: how to write a biography for children [Electronic resource]. URL: https://blog.leeandlow.com/2012/05/09/writing-alife-how-to-write-a-biography-for-children/ (retrieved 11/21/2018).

9. Лотман Ю. Биография - живое лицо [Электронный ресурс] // Новый мир. 1985. № 2. URL: ftp://ftp.slav.su.se/pub/slav/kursmaterial/ry2/sakprosa/ H04/biografi.pdf (дата звернення: 22.11.2018).

10. Літературознавчий словник-довідник [Електронний ресурс]. Київ: Академія, 2007. URL: http://chtyvo.org.ua/authors/Hromiak_Roman/ Literaturoznavchyi_slovnyk-dovidnyk/ (дата звернення: 22.11.2018).

11. Казакова Г. Нон-фикшн в современной книжной культуре / Г. Казакова // Вестн. Челябинской гос. акад. культуры и искусств. 2016. № 3. С. 7-12.

12. Огар Е. Сучасна нон-фікшн для дітей: структурні та функціональні характеристики / Е. Огар // Наук. зап. Укр. акад. друкарства. 2012. № 2. С. 41.

\section{References}

1. Cherkashyna, T. (2007). Naratyvni osoblyvosti hudozhno-biohrafichnoi prozy. Ternopil, 22 p. [in Ukrainian].

2. Marchenko, N. (2011). Sotsiokulturni stereotypy v novitnii ukraiinskii biohrafitsi dlia ditei. Journal of Bibliotechnyi visnyk, 1, 149-174 [in Ukrainian].

3. Marchenko, N. (2010). Biohrafichna informatsiia u vydanniakh dlia ditei u konteksti suchasnykh zavdan biohrafistyky. Journal of Ukraiinska biohrafistyka, 7, 105-144 [in Ukrainian]. 
4. Semenchenko, M. (2010). I henii buly malymy. Retrieved November 22, 2018, from http://litakcent.com/ 2010/09/10/i-heniji-bulymalymy.html [in Ukrainian].

5. Halych, O. (2013). Fiction i non Fiction v literaturi: problemy teorii ta istorii. Luhansk: SPD Rieznikov, 368 p. [in Ukrainian].

6. Kolinko, O. (2016). Non-fikshn iak osoblyvyi fenomen suchasnoi beletrystyky. Journal of Naukovyi visnyk Mizhnarodnoho humanitarnoho universytetu, 24, 76-78 [in Ukrainian].

7. Ovdiichuk, L. (2014). Zhanrovo-styliovi osoblyvosti suchasnoi biohrafichnoi prozy dlia ditei. Journal of Pytannia literaturoznavstva, 90, 156-169 [in Ukrainian].

8. Schroeder, A. (2012). Writing a life: how to write a biography for children. Retrieved November 22, 2018, from https://blog.leeandlow.com/2012/05/09/ writing-a-life-how-to-write-a-biography-for-children/ [in English].

9. Lotman, Ju. (1985). Biohrafiia - zhivoe litso. Retrieved November 22, 2018, from ftp://ftp.slav.su.se/pub/slav/kursmaterial/ry2/sakprosa/H04/ biografi.pdf [in Russian].

10. (2007). Literaturoznavchyi slovnyk-dovidnyk. Kyiv: Akademiia. Retrieved November 22, 2018, from http://chtyvo.org.ua/authors/Hromiak_Roman/ Literaturoznavchyi slovnyk-dovidnyk/ [in Ukrainian].

11. Kazakova, H. (2016). Non-fikshn v sovremennoi knizhnoi kulture. Journal of Vestnik Chelyabinskoy gosudarstvennoy akademii kulturyi i iskusstv, 3, 7-12 [in Russian].

12. Ohar, E. (2012). Suchasna non-fikshn dlia ditei: strukturni ta funkcionalni kharakterystyky. Journal of Naukovi zapysky Ukraiinskoi akademii drukarstva, 2, 41-43 [in Ukrainian].

Исследованы биографические издания о выдающихся личностях, предназначенные для детской читательской аудитории. Установлено, что всё чаще авторы отходят от традиционных энциклопедических форм представления биографий по принятым схемам, склоняясь в сторону художественного изложения. Охарактеризованы принципы отбора фактов и выявлено разнообразие приемов популяризации выдающихся личностей в украиноязычных беллетризованных биографиях для детей; раскрыт воспитательный потенциал таких изданий. Жанр беллетризованной биографии позволяет персонализировать историю, развивать мотивацию, пробуждать потребность в познании окружающего мира, сопровождая взросление и социализацию юного читателя. Среди канонов построения беллетризованной биографии можно выделить правдивость изображения главного героя, использование лингвостилистических средств, глубокое погружение в психологию личности, отбор интересных и шокирующих фактов, гармоничное сочетание правды и вымысла. 
Ключевые слова: беллетризованная биография; художественно-биографическое произведение;

биографическая проза; популяризация; детская аудитория.

The biographical publications on outstanding personalities for the children's readership are researched. It is revealed that authors are increasingly moving away from traditional encyclopedic forms of biography presentation under established schemes, bending to a fiction presentation. The principles of the facts selection were characterized and the variety of popularization methods of outstanding personalities in the Ukrainian-language biblical biographies for children was revealed. The educational potential of such publications is disclosed. Author should dive into the chronicles, memoirs, diaries, letters, memories of the contemporaries of the person concerned, as well as reference and fiction, in order to draw a general plot of the narrative, and then fill this plot with the most interesting facts and bright details, while weighing each time their importance and ability to impress the reader. In this case, the author has to take into account that the person is formed under the influence of the era adopted in the society at that time, moral and ethical norms and behavior patterns.

Keywords: biography; artistic and biographical text; biographical prose; popularization; children's audience. 